\title{
Effect of water regime and varietal differences on yield and its components of sesame
}

\author{
Amal G. Ahmed, Nabila M. Zaki and M. S. Hassanein
}

Field Crops Research Department, Agricultural and Biological Research Division, National Research Centre, 33 El Buhouth St., (Former El Tahrir St.) 12622 Dokki, Giza, Egypt

Received: 05 August 2019/ Accepted 10 Oct. 2019/ Publication date: 20 Oct. 2019

\begin{abstract}
Two field experiments were conducted at Wadi El-Rayyan, Fayoum governorate, Egypt, during 2017 and 2018 seasons. The objective of this study was to investigate the effect of water regime and varietal differences on yield and yield components of sesame plants. Water regime treatments i.e. (Normal irrigation, omitting the $3^{\text {rd }}$ irrigation, omitting the $4^{\text {th }}$ irrigation and omitting the $5^{\text {th }}$ irrigation) were added in the main plots, while the two sesame cultivars Shandwell-3 and Sohag-1 were allocated in the sub plots. The results could be summarized as follows:

It is clear from data that water regime had a significant effect on yield and its components, where normal irrigation gave the highest values followed by omitting the $5^{\text {th }}$ irrigation in all characters under study (plant height, number of branches/ plant, dry weight (g)/plant, number of capsules/plant, weight of capsules $(\mathrm{g}) / \mathrm{plant}$, seeds yield $(\mathrm{g}) / \mathrm{plant}$, straw yield $(\mathrm{kg}) / \mathrm{fed}$., seed yield $(\mathrm{kg}) / \mathrm{fed}$. and biological yield $(\mathrm{kg}) / \mathrm{fed}$.) except shelling percentage, seed and harvest index where omitting the $5^{\text {th }}$ irrigation surpassed other treatments.

Sohag-1 cultivar surpassed Shandwell-3 cultivar in all studied characters except shelling percentage and harvest index.

Regarding of the interaction between water regime and sesame cultivars results showed that there were significant differences in yield and its components characters except dry weight (g)/plant and seed index $(\mathrm{g})$.
\end{abstract}

Keywords: Sesame, cultivars, water regime, omitting, yield and its components.

\section{Introduction}

Sesame (Seasamum indicum L.) could be considered as one the most important oil crops in the world. It seeds have a high content of oil and protein. In Egypt, the expanding in its cultivation should be taken in newly cultivated sandy soils, but its facing many problems such as drought stress. Sesame (Seasamum indicum L.) otherwise known as sesamum or benniseed, member $\mathrm{c}$ of the family Pedaliaceae, is one of the most ancient oilseed crop known to mankind. Sesame plays an important role in human nutrition. Most of the seeds are used for oil extraction and the rest are used for edible purposes (El-Khier et al., 2008). In Egypt, sesame is considering a food crop rather than oilseed crops. The production of sesame is not sufficient to provide the needs for its oil and seed. Therefore, it is necessary to increase sesame seed yield to meet the demands for both oil and seeds. This could be achieved by using high yielding varieties (Basha, 1998). Drought stress is one of the major abiotic stresses in agriculture worldwide. Increasing crop tolerance to water limitation would be the most economical approach to enhance productivity and reduce agricultural use of fresh water resources (Gao et al., 2008). Water is essential at every stage of plant growth, from seed germination to plant maturation (Turner, 1991). As a results of water deficit stress, the physiology of crop is disturbed this causes a large number of changes in morphology and anatomy of plant and it had many effects on growth and yield of the crop (Ashraf, and O'Leary, 1996). Increase the irrigation interval reduced yield and its components (Anwar et al., 1995).

Thus the objective of this study is to investigate the effect of water regime and on yield and its components of two sesame cultivars.

Corresponding Author: Amal G. Ahmed, Field Crops Research Department, Agricultural and Biological Research Division, National Research Centre, 33 El Buhouth St., (Former El Tahrir St.) 12622 Dokki, Giza, Egypt 


\section{Materials and Methods}

Two field experiments were conducted at Wadi El-Rayyan region, Fayoum governorate, Egypt, during the two successive growing seasons 2017 and 2018 to study the effect of water regime and varietal differences on yield and its components of sesame plants. The physical and chemical properties of the experimental soil site $(30 \mathrm{~cm}$ depths) were as follows: sand $53.5 \%$, silt $20 \%$, clay 26.5\%, PH 8.00, OM 0.82\%, CaCO3 20.9\%, EC $2.9 \mathrm{~mm}$ hos/cm3, soluble $\mathrm{N} 74$ ppm according to Chapman and Pratt (1961).

The experimental design was split-plot design with four replications, water regime (normal irrigation as a control, omitting the $3^{\text {rd }}$ irrigation, omitting the $4^{\text {th }}$ irrigation and omitting the $5^{\text {th }}$ irrigation) were randomly assigned in the main plots, the sesame cultivars (Shandwell-3 and Sohag-1) were randomly allocated at sub plots. Every experimental included 8 treatments which were the combinations of water regime and two cultivars. Each plot consisted of 6 ridges 3.5 meters in length and $50 \mathrm{~cm}$ in width (plot area was $10.5 \mathrm{~m}^{2}$ ). Seeds of sesame were sown on one side of the ridge in hills $15 \mathrm{~cm}$ apart on May 10, and 15 in 2017and 2018 seasons, respectively. After 21 days from sowing, sesame plants were thinned to two plants per hill. The normal cultural practices for growing sesame crop were followed.

At harvest time, after 110 days from sowing, samples of 10 guarded plants were randomly taken from inner ridges in each sub plot to estimate plant height $(\mathrm{cm})$, number of branches / plant, dry weight (g)/plant, number of capsules/plant, weight of capsules $(\mathrm{g}) / \mathrm{plant}$, seed yield (g)/plant, shelling $\%$, and seed index. Seed yield $\mathrm{kg} /$ fed., straw yield $\mathrm{kg} / \mathrm{fed}$., biological yield $\mathrm{kg} / \mathrm{fed}$., and harvest index were determined from the plants of the two middle ridges in each sub plot.

The analysis of variance of split plots design was used according to Gomez and Gomez (1984), and combined analysis was made for the two growing seasons as results followed similar trends. Comparison between means L.S.D. test at 0.05 level was used.

\section{Results and Discussion}

\section{1-Effect of water regime:}

As can be seen from table (1) water stress significantly decreased all characters of yield and yield components i.e. plant height $(\mathrm{cm})$, number of branches / plant, dry weight $(\mathrm{g}) / \mathrm{plant}$, number of capsules/plant, weight of capsules $(\mathrm{g}) /$ plant, seed yield $(\mathrm{g}) /$ plant, shelling percentage, seed index, straw yield $\mathrm{kg} /$ fed., seed yield $\mathrm{kg} /$ fed., biological yield $\mathrm{kg} /$ fed., and harvest index. It is clear from data that the highest mean value of all characters under study were obtained from normal irrigation followed by omitting the $5^{\text {th }}$ irrigation, omitting the $4^{\text {th }}$ irrigation and then by omitting the $3^{\text {rd }}$ irrigation, except shelling percentage, seed index and harvest index were obtained from omitting the $5^{\text {th }}$ irrigation. Effect of water stress is usually accompanied with limited photosynthesis and decrease in photosynthesis leads to decrease in yield (Mwanamwenge et al., 1999 and Ahmed et al., 2015 and 2016). If water stress occurs during earliest stages of plant, seed yield will be decreased (Ahmed et al., 2016). It is clear that water stress decreases cell division and cell elongation. It is clear that normal irrigation increased rate of photosynthesis and better translocation of photosynthtes from leaves and stem to sink. Photosynthesis is limited by drought stress due to stomatal (stomatal closure) and non stomatal (impairments of metabolic processes) factors, resulting in less assimilate production for growth and yield of plants (Mafakheri et al., 2010). The results are almost same as were reported by (Ghassemi-Golezani et al., 2008, Ahmed et al., 2013 and Zaki et al., 2013). They reported that yield and its components were significantly affected by irrigation regime (Ahmed et al., 2016). The higher yield /fed. under normal irrigation can be attributed to higher weight of capsules (g)/ plant and seed yield (g)/ plant. The increased crop yield may be due to more partitioning of dry matter to reproductive parts. Gunes et al. (2008) found that decreasing water availability under drought conditions generally results in reduced total nutrient uptake.

\section{2- Effect of varieties:}

Results in table (1) indicated that there were significant differences between the two cultivars of sesame for all characters under study in both seasons. It is clear from data that sohag-1 cultivar surpassed shandawell-3 cultivar in plant height $(\mathrm{cm})$, number of branches / plant, dry weight $(\mathrm{g}) / \mathrm{plant}$, number of capsules/plant, weight of capsules $(\mathrm{g}) /$ plant, seed yield (g)/plant, straw yield kg/fed., seed 
Table 1: Effect of water regime and varietal differences on yield and its components of sesame. (Average of 2017 and 2018 seasons)

\begin{tabular}{|c|c|c|c|c|c|c|c|c|c|c|c|c|}
\hline Characters & $\begin{array}{c}\text { Plant } \\
\text { height }(\mathrm{cm})\end{array}$ & $\begin{array}{c}\text { Number of } \\
\text { branches } \\
\text { /plant }\end{array}$ & $\begin{array}{c}\text { Dry } \\
\text { weight } \\
\text { of plant } \\
\text { (g) }\end{array}$ & $\begin{array}{c}\text { Number } \\
\text { of } \\
\text { capsules } \\
\text { /plant }\end{array}$ & $\begin{array}{c}\text { Weight of } \\
\text { capsules/plant } \\
\text { (g) }\end{array}$ & $\begin{array}{c}\text { Seed } \\
\text { yield } \\
\text { /plant } \\
(\mathrm{g}) \\
\end{array}$ & $\begin{array}{c}\text { Shelling } \\
\%\end{array}$ & $\begin{array}{c}\text { Seed } \\
\text { index } \\
(\mathrm{g})\end{array}$ & $\begin{array}{c}\text { Straw } \\
\text { yield (kg) } \\
\text { /feddan }\end{array}$ & $\begin{array}{c}\text { Seed } \\
\text { yield (kg) } \\
\text { /feddan }\end{array}$ & $\begin{array}{l}\text { Biological } \\
\text { yield (kg) } \\
\text { /feddan }\end{array}$ & $\begin{array}{l}\text { Harvest } \\
\text { index \% }\end{array}$ \\
\hline \multicolumn{13}{|c|}{ Water regime } \\
\hline Normal irrigation & 152.70 & 3.35 & 187.64 & 53.25 & 70.22 & 42.73 & 60.11 & 3.70 & 1112.29 & 821.73 & 1933.84 & 42.45 \\
\hline Omitting $3^{\text {rd }}$ irrigation & 142.36 & 2.95 & 173.73 & 46.95 & 60.42 & 35.38 & 58.26 & 3.38 & 1053.19 & 692.75 & 1740.52 & 39.76 \\
\hline Omitting $4^{\text {th }}$ irrigation & 146.36 & 3.17 & 180.39 & 48.65 & 63.43 & 37.39 & 60.69 & 3.55 & 1088.58 & 772.67 & 1860.75 & 41.56 \\
\hline Omitting $5^{\text {th }}$ irrigation & 151.26 & 3.28 & 184.43 & 51.22 & 66.28 & 40.49 & 62.18 & 3.73 & 1082.69 & 809.95 & 1892.12 & 42.49 \\
\hline L.S.D at $5 \%$ & 1.48 & 0.11 & 2.39 & 1.09 & 0.41 & 1.64 & 0.90 & 0.13 & 13.45 & 18.03 & 29.74 & 0.66 \\
\hline \multicolumn{13}{|c|}{ Cultivars } \\
\hline Sohag -1 & 151.94 & 4.06 & 185.51 & 51.24 & 66.95 & 39.44 & 59.49 & 3.71 & 1113.50 & 783.33 & 1894.56 & 41.25 \\
\hline L.S.D. at $5 \%$ & 1.29 & 0.06 & 1.01 & 0.72 & 0.31 & 0.36 & 0.71 & $\mathbf{0 . 0 7}$ & 3.46 & 6.21 & 7.18 & 0.27 \\
\hline
\end{tabular}

Table 2: Effect of interaction between water regime and varietal differences on yield and its components of sesame. (Average of 2017 and 2018 seasons)

\begin{tabular}{|c|c|c|c|c|c|c|c|c|c|c|c|c|c|}
\hline Treatments & Characters & $\begin{array}{c}\text { Plant } \\
\text { height } \\
(\mathrm{cm})\end{array}$ & $\begin{array}{c}\begin{array}{c}\text { Number } \\
\text { of } \\
\text { branches }\end{array} \\
\text { /plant }\end{array}$ & $\begin{array}{c}\text { Dry } \\
\text { weight } \\
\text { of } \\
\text { plant } \\
\text { (g) }\end{array}$ & $\begin{array}{c}\begin{array}{c}\text { Number } \\
\text { of } \\
\text { capsules }\end{array} \\
\text { /plant }\end{array}$ & $\begin{array}{c}\begin{array}{c}\text { Weight } \\
\text { of } \\
\text { capsules }\end{array} \\
\text { /plant(g) }\end{array}$ & $\begin{array}{l}\text { Seed } \\
\text { yield } \\
\text { /plant } \\
(\mathrm{g})\end{array}$ & $\begin{array}{c}\text { Shelling } \\
\%\end{array}$ & $\begin{array}{c}\text { Seed } \\
\text { index } \\
(\mathrm{g})\end{array}$ & $\begin{array}{c}\text { Straw } \\
\text { yield } \\
(\mathrm{kg}) \\
\text { /feddan }\end{array}$ & $\begin{array}{c}\text { Seed } \\
\text { yield } \\
(\mathrm{kg})\end{array}$ & $\begin{array}{c}\text { Biological } \\
\text { yield (kg) } \\
\text { /feddan }\end{array}$ & $\begin{array}{c}\text { Harvest } \\
\text { index } \\
\%\end{array}$ \\
\hline \multicolumn{14}{|c|}{ Water regime $\mathrm{x}$ Cultivars } \\
\hline \multirow{2}{*}{ Normal irrigation } & Shandwell-3 & 146.55 & 2.34 & 183.16 & 51.25 & 69.26 & 41.22 & 58.01 & 3.51 & 1091.17 & 792.29 & 1883.35 & 41.98 \\
\hline & Sohag -1 & 158.85 & 4.36 & 192.13 & 55.25 & 71.18 & 44.23 & 62.20 & 3.88 & 1133.40 & 851.17 & 1984.33 & 42.91 \\
\hline Omitting $3^{\text {rd }}$ irrigation & Shandwell-3 & 140.40 & 2.03 & 170.23 & 46.46 & 58.22 & 36.08 & 60.86 & 3.26 & 1030.20 & 710.97 & 1737.73 & 40.95 \\
\hline \multirow{2}{*}{ Omitting $4^{\text {th }}$ irrigation } & Shandwell-3 & 143.47 & 2.43 & 176.38 & 47.87 & 61.15 & 36.94 & 62.46 & 3.43 & 1064.15 & 763.60 & 1827.27 & 41.79 \\
\hline & Sohag -1 & 149.25 & 3.91 & 184.40 & 49.43 & 65.70 & 37.84 & 58.92 & 3.66 & 1113.00 & 781.73 & 1894.23 & 41.33 \\
\hline \multirow{2}{*}{ Omitting $5^{\text {th }}$ irrigation } & Shandwell-3 & 147.17 & 2.45 & 180.55 & 49.60 & 64.26 & 39.97 & 63.18 & 3.68 & 1033.94 & 794.00 & 1827.87 & 42.76 \\
\hline & Sohag -1 & 155.34 & 4.10 & 188.30 & 52.85 & 68.30 & 41.02 & 61.17 & 3.78 & 1131.43 & 825.90 & 1956.37 & 42.21 \\
\hline L.S.D. at 5\% & & 2.59 & 0.11 & n.s & 1.44 & 0.63 & 0.72 & 1.42 & n.s & 6.92 & 12.41 & 14.37 & 0.54 \\
\hline
\end{tabular}


yield $\mathrm{kg} / \mathrm{fed}$., and biological yield $\mathrm{kg} / \mathrm{feddan}$. At the same time shandawell-3 cultivar superiority the other cultivar in seed index (g), shelling percentage and harvest index.

The difference between the two sesame cultivars was confirmed by several researches Basha (1994), Awaad and Basha (2000), Guo and Guo (2000) and Ottai et al., (2005). Cultivars differences may be due to differences in growth characters Ahmed et al., (2010a and b). The differences between cultivars in yield and its component in sesame may be due to the genetic differences. Also, the differences in 1000 seed weight might be attributed to the cultivars in translocation rate of photosynthate from leaves to the storing organs i.e. the seed. These finding are in similar trend with those of Zaki et al., (2004 and 2007), Ahmed et al., (2010a and b), Zaki et al., (2012) and Ahmed et al., (2015).

\section{3-Effect of interaction:}

The interaction between water regime and cultivars of sesame are presented in table (2). Data indicated the interaction of water regime and cultivars of sesame was significant in all characters under study in both seasons i.e. plant height $(\mathrm{cm})$, number of branches / plant, number of capsules/plant, weight of capsules (g)/plant, seed yield (g)/plant, shelling percentage, straw yield $\mathrm{kg} /$ fed., seed yield $\mathrm{kg} /$ fed., biological yield $\mathrm{kg} / \mathrm{fed}$., and harvest index except dry weight $(\mathrm{g}) / \mathrm{plant}$ and seed index (g). The highest values of all characters under study was normal irrigation with sohag-1 cultivar followed by omitting the $5^{\text {th }}$ irrigation with sohag-1 cultivar except shelling percentage was omitting the $5^{\text {th }}$ irrigation with shandawell-3 cultivar.

\section{References}

Ahmed, A.G., M.A. Ahmed, M.S. Hassanein and N.M. Zaki, 2010a. Effect of organic and biofertilization on growth and yield and yield components of two chickpea cultivated land. J. of Applied Sci. Research, 6 (12): 2000- 2009.

Ahmed, A. G., M. S. Hassanein and N. M. Zaki, 2016. Effect of water regime and varietal differences on yield, its components and chemical constituent of Sunflower plant. Inter. J. of Pharm Tech Research, 9 (12): 1048-1057.

Ahmed, A. G., M.S. Hassanein, N. M. Zaki, R. Kh. M. Khalifa and E. A. Badr, 2015. Effect of BioNP Fertilizer on Yield, Yield Components and some Biochemical Components of two Sesame Varieties. Middle East J. Appl. Sci., 5(3): 630-635.

Ahmed, A.G., M. H. Mohamed, M. S. Hassanein, N.M. Zaki, S.F. El-Habbasha, M.M. Tawifk and M. F. Mohamed, 2015. Effect of Water Regime and Potassium Fertilization on Productivity of Two Chickpea (Cicer arietinum L.) Cultivars. Inter. J. of Chem Tech Res., 8 (4):1509-1519.

Ahmed A.G., S.A. Orabi, and M.S. Gaballah, 2010b. Effect of bio. N.P. fertilizer on the growth, yield and some biochemical components of two sunflower cultivars. Inter. J. of Academic Res., 2(4):271-277.

Ahmed, A. G., N. M. Zaki, M. H. Mohamed, M. M. Tawfik and M. S. Hassanein, 2013. Growth and Yield Response of Two Chickpea Cultivars (Cicer arietinum L.) to Skipping One Irrigation. Middle East J. Agri. Res., 2(4): 146-151.

Anwar, M., S. Rehman, S. Khan and Z. Quarishi, 1995. Response of sunflower varieties to different irrigation regimes during Kharif season in Peshawar Valley. Sarhad J. Agric., 11: 273-278.

Ashraf, M. and J.W. O'Leary, 1996.Effect of drought stress on growth, water relations and gas exchange of two lines of sunflower differing in degree of salt tolerance. Int. J. Plant Sci., 157: 729-732.

Awaad, H.A. and H.A. Basha, 2000. Yield potentiality and yield analysis of some sesame genotypes grown under two plant population densities in newly reclaimed sandy soils. Zagazig J. Agric. Res., 27: 239-253.

Basha, H.A., 1994. Response of two sesame cultivars to nitrogen level in newly reclaimed sandy soil. Zagazig. J. Agric. Res., 21 (3A): 614-616.

Basha, H.A., 1998. Response of some sesame varieties to different row and hill spacing in newly cultivated sandy soil. Zagazig J. Agric. Res., 25 (3):385-397.

Chapman, H. D., and P.F. Pratt, 1961. Methods of Analysis for soils, plants and water. Univ. California, Berkeley, CA, USA. 
El-Khier, M.K.S., K.E.A. Ishag and A.E.A. Yagoub, 2008. Chemical composition and oil characteristics of sesame seed cultivars grown in Sudan. Res. J. Agric. and Biol. Sci. 4(6): 761766.

Gao, W.R., X.S.H. Wang, P. Liu, J.G. Li and H. Ma. Zhang, 2008. Comparative analysis of ESTs in response to drought stress in chickpea (Cicer arietinume L.). Bioch. Bioph. Res. Commu., 376, 578-583.

Ghassemi-Golezani k., B. Dalil, A.D. Muhammadi-Nasab and S. Zehtab-Salmasi, 2008. The response of chickpea cultivars to field water deficit. Not. Bot. Hor. Agro. Cluj-Napoca 36, 25-28.

Gomez, A. K. and A. A. Gomez, 1984.Statistical procedure for agricultural Research. $2^{\text {nd }}$ edition John Wiley and Sons, nc., New York.

Gunes, A., A. Inal, M. S. Adak, E. G. Bagci, N. Cicek and F. Eraslan, 2008. Effect of drought stress implemented at pre- or post- anthesis stage some physiological as screening criteria in chickpea cultivars. Russ. J. Plant. Phy., 55, 59-67.

Guo, T.J. and T.J. Guo, 2000. The availability of G. types bio-fertilizered (GBF) and its impact upon ecosystems, plant growth and nutrient stateus. Res. Pro. In Plant Port. And Nut, 79: 416-427.

Mafakheri, A., B. Siosemardeh, P.C. Bahramnejad and Y. Sohrabi, 2010. Effect of drought stress on yield, proline and chlorophyll contents in three chickpea varieties. Austr. J. Crop Sci., 4,580585.

Mwanamwenge, J., S.P. Loss, K.H.M. Siddique and P.S. Cocks, 1999. Effect of water stress during floral initiation, flowering and podding on the growth and yield of faba bean (Vicia faba L.). Eur. J. Agron., 11: 1-11.

Ottai, M.E.S, M.M. Ibrahim and M.S. Hassanein, 2005. Performance of different sesame (Sesamum indicum L.) varieties under variable environments. Annals Agric. Sci., Ain Shams Univ., Cairo, 50 (1), 229-245.

Turner, L.B., 1991.The effect of water stress on the vegetative growth of white clover (Trifolium epens L.): Comparison of long-term water deficit and short-term developing water stress. J. Exp. Bot., 42: 311-316.

Zaki, N.M., M.A. Ahmed and M.S. Hassanein, 2004. Growth and yield of some wheat cultivars irrigated with saline water in newly cultivated land as affected by nitrogen fertilization. Annals of Agric. Sci. Moshtohor, 42 (2):515 -525.

Zaki, N. M., A. G. Ahmed, M. H. Mohamed, M. M. Tawfik and M. S. Hassanein, 2013. Effect of Skipping one Irrigation and Potassium Fertilization on Growth and Yield of Chickpea Plants. World Appl. Sci. J., 27(5): 557-561.

Zaki, N.M., M.A. Gomaa, F.I. Radwan, M.S. Hassanein and A.M. Wali, 2012. Effect of mineral, organic and bio-fertilizers on yield, yield components and chemical composition of some wheat cultivars. Journal of Applied Sciences Research, 8(1):174 -191.

Zaki, N.M., M.S. Hassanein and K.M. EL-Din, 2007. Growth and yield of some wheat cultivars irrigated with saline water in newly cultivated land as affected by biofertilization. J. of Applied. Sci. Research, 3(10): 1121-1126. 